\title{
FINANCIAL INSTITUTIONS IN THE LEGAL SYSTEM OF ISLAMIC BANKING AND LEGAL DISPUTE SETTLEMENT
}

\author{
Akhmad Khisni \\ Law Faculty of Sultan Agung Islamic University \\ akhmadkhisniunissula@gmail.com
}

\begin{abstract}
Islamic financial institutions in Indonesia are legalized in the governance of the banking law and in case of legal disputes become the absolute authority of the Religious Courts. Religious Courts readiness in responding to the development Islamic economics and resolve legal disputes are inevitable in the conduct of religious courts function as a legal institution, namely enforcement of certainty (juridical aspects) and justice (philosophical aspect), in addition to running the social aspects (sociological aspect). The position of Justice of religion as a social institution is dynamic, because of the exchange with the community dynamics that require the judge to explore, and understand the value of the law who live in the society. The implementation of Act No.3 of 2006 as amended by Act No. 50 Of 2009 regarding the Second Amendment to Act No.7 of 1989 concerning the Religious Courts, reinforced by Act No. 21 of 2008 concerning Islamic Banking. Institutional constraints faced by the Religious Court in handling cases Islamic economics is the law enforcement factors, factors of infrastructure, the judge in the religious courts appeared to be not effective due to the number of judges who have not been certified Islamic economy is still lacking, and the lack of educational and training of human resource development. In a more holistic approach to address the above problems, it is necessary reconstruction of the arrangement of the legal system and legal institutions and legal culture arrangement.
\end{abstract}

Keywords: Islamic Financial; Banking Law; Settlement Of Legal Disputes.

\section{A. INTRODUCTION}

Islam derived in this world is rahmatan lil 'alamiin (affection for all natural). In Islamic doctrine, in which there are dimensions of faith, morals and the end goal is to form a human (natural person) happy and prosperous in the world and in the hereafter (Sa'adah fi addaraini). Such things can be achieved if the fulfillment of the "almashalih al-khamsah" (The five of kindness), namely: the maintenance (1) religion, (2) people, (3) reasonable, (4) descent, and (5) property object. The maintenance of the five primary of life needs (dharuriyah) it is one system (unity) are intertwined should exist and balanced, if one sub. system nothing will interfere with the achievement of these objectives.

In Realizing the people's welfare, the economic aspect of the country Becomes very important to be organized and strived. The economic aspect is very supportive of the progress of a nation. 1 One sub-system

1 Bambang Suprabowo, Anis Mashdurohatun and Eman Suparman, The Inhibiting Factors On Legal Protection For Recipients of Fidusiary Warranties With Guaranted Inventory Objects, South East Asian 
needs a very cared for and protected by Islamic law is the "preservation of property". Property in Islamic doctrine is of primary (principal) in human life. Property as a tool (wasail), not as an end (maqashid) life, but decisive in achieving the goals of Moslem life.

Property in Islamic doctrine regulated normative in Islamic economic law. In the Islamic economic system can not be separated and must be breathed Islamic values (Divine values) and this is what distinguishes the capitalist economy, which is only oriented economic principles that made the "smallest sacrifice and profits a big "effect occurs is" oppression ", there is no equity value (balance), please help (ta'awun), and the principle of non persecutors and not persecuted (la dharara wa la dhirara) contained in the" principles of Islamic economics ".

Islamic economic paradigm of today, more and more interesting to learn. The real world situation is now pushing more and more policymakers in the field of economics that seriously doubt the "universality", productivity, and even morality is a fundamental assumptions and basic conception of the paradigm. Many theories about the economy, it has failed to reality and real condition, so that the paradigm of economic theory needs to formulations and methodologies to find a new paradigm. 2 In theory and economic paradigm as a framework of ethics and fairness in a frame work in people's lives are still far from expectations.

Journal of Contemporary Business, Economics and Law, Vol. 13, Issue 4 (Augustl), 2017, p.117.

2 Syed Nawab Haider Nagvi 1981, Ethies and Economics: An Islamic Synthesis, The Islamic Foundation, Leicester, p.8.
Economy and economic partnership in the framework of economic development in Indonesia in order to achieve prosperity and equity in economic sectors received a positive response operators. In fact, the people's economy in the socioeconomic context "in Islam" is part of the vision of magnitude in universal ethics. This means that the formulation of a valid statement of the basis, process and economic motivation in Islamic societies that reflect the ideal Moslem society. These statements reflect the value containing of objective validity and are part Islamic economics that attempts to explain the need for economic representative of Moslem (Islamic economics/sharia) in the community.

The development Islamic financial institutions (sharia) in Indonesia is one manifestation above assumptions, the basic concept that reflects the economic development in the Moslem community's economy. Indonesian community development undertaken a thorough development as well as touching all aspects of community life in the sense that not only focuses on one particular field. Development in the field of economics is a major driver of development, yet this should be accompanied by economic development are mutually reinforcing efforts, relevant, and integrated with other areas of development.

Economic development relationship with the law have a reciprocal relationship and closely. Sunarjati Hartono3 states: Renewal of

3 Sunarjati Hartono, 1982, Hukum Ekonomi 
the foundations of thought in economics helped change and define the basics of the legal system is concerned, the rule of law principles are appropriate will also facilitate the establishment of economic structure desired, but otherwise the enforcement of legal principles that do not fit precisely will impede the achievement of the economic structure is aspired.

Law is one of the areas that need to be built for strengthen the Indonesian nation in the face of progress seta development of science, technology and art are very rapid. The legal issue is not a problem that stands alone, but is closely related to other societal problems. Ismail Saleh4 states, the economy is the backbone of public welfare, and it is true that science and technology are the pillars supporting the progress of a nation, but there is no denying that the law is an institution that ultimately determine how the relative prosperity can be enjoyed equitably, how justice social can be realized in people's lives, how advances in science and technology can bring happiness to the people.

In a study of the legal aspects of economic activities are generally carried out by economic actors both individuals who run companies or entities either have accrued as a legal entity or non-legal entity. According to Sri Redjeki Hartono5 gives the sense that the economic activity in question is an activity that should be carried out

Pembangunan Indonesia, Bina Cipta, Bandung, p.6-7.

4 Ismail Saleh, 1990, Hukum dan Ekonomi, PT. Gramedia Pustaka Utama, Jakarta, p.28.

5 Sri Redjeki Hartono, 2000, Kapita Selekta Hukum Ekonomi, Editor, Husni Syawali and Neni Sri Imaniyati, Masdar Maju, Bandung, p. 4. continuously (uninterrupted) explicitly in terms of legitimate, and the activities carried out in order to gain an advantage.

The economic activity in the community is essentially a series of different activities may pose legal and/spawned a variety of legal consequences so extensive that ultimately makes the rights and responsibilities for many parties with different shapes in different variations. From the background of the problems mentioned above, can be raised the problem as follows: How does the existence of a financial institution Islam in the legal system of banking and legal dispute settlement authority.

\section{B. DISCUSSION}

Realize a just and prosperous society is a trust that must be implemented by the government based on Pancasila and the Constitution of 1945. The continuation and improvement of the implementation of national development family, needs to be maintained properly. In order to achieve these objectives, the implementation of economic development should be focus to harmony, and balance the elements of equitable development, economic growth and national stability. 6

One of the tools that have a strategic role in development is the Bank. Strategic role is mainly attributable to the bank's main function as a vehicle to raise and channel public funds effectively and efficiently. Noting the role of banking institutions as

6 General Explanation of Law No. 7 of 1992 on Banking, and the Act was amended by Act No. 10 of 1998 on the Amendment to Act No. 7 of 1992 on Banking. 
strategic in achieving national development, then to banking institutions need to constantly there is guidance and effective supervision, born out of the foundation of motion solid that Indonesian institution is able to function efficiently, healthy, fair and able to protect in both funds these communities into productive areas to the achievement of development means.

In accordance with the System of Economic Democracy, published in the MPR No.IV / MPR / 1999 on Broad Outlines of State Policy (Guidelines, that partisanship and populist economic empowerment is related to the background to the legislation governing the banking issues, including Islamic banking in Indonesia. it is no exaggeration that the populist economic development can not be separated from the development of an "economy of Moslems". because Moslems are the people of the majority of the Indonesian population with a $87 \%$ Moslem. Therefore, if done in the national economic development of equitable manner vertical and horizontal, then it means the development of the economic power of Islam.7

Siding with the people's economy, Actually not just as a form of siding with the people's economy but is a form of appropriate development strategy to achieve the welfare of the people of Indonesia. So the populist economic development directed towards efforts to involve the people in economic development, people's efforts

7 Dawam Rahardjo, 1999, Islam dan Transformasi Sosial-Ekonomi, LSAF, Jakarta, p.369. to improve productivity, increase the purchasing power of the people, creating jobs for the people, and foster economic values for economic sector that was involved people. The participation and role in the development of increasingly important nation through economic empowerment, supported the national banking and financial institutions to reach out to all levels of the business community economy.

Therefore, in the Act No. 10 of 1998 on the Amendment of Act No. 7 of 1992 on Banking There are many substantial changes. Among the main points of these changes, among others, about the affirmation of the independence of Bank Indonesia in the guidance and supervision of banks, the establishment of a special agency in bank restructuring, and ease of implementation of the principles Islam in banking operations. Changes in the Banking Law raises great expectations for growth and development of Islamic Banking in Indonesia.

The ease of the principles Islam in national banking and the hope and desire that is long enough by Indonesian Moslems. Islamic principle better known as revenue sharing system by eliminating the principle of interest or usury in conventional banking is a challenge and an expectation in the national banking world. But on the other hand, the banking system Islam in banking law and economic law preparedness needs to get priority and a separate study in the economic legal system in Indonesia. Empowerment of Islamic banking and financial system should start from the root emergence idea to 
develop a financial system based on Islamic teachings. This system was seen as an alternative way out, as well as the needs of the Islamic financial system. It can be seen after a failure of the capitalist financial system that developed in Indonesia, which was adopted from the west, culminating with the monetary crisis and the impact on the economic crisis, the prolonged political in Indonesia.

The division of the world into two competitive economic system, namely: (1) the capitalist and (2) socialism. Moslems feel the need to decide how to plan their lives. There are two schools of thought on this particular issue. First, incorrectly directed by the glamor of west civilization, can not think of the application Islam principles into economic life issues. Second, in obedience to the divine law, assumes that Islam as a religion that is universal and covers all issues in which embody the principles of economics that is permanent, can restore life in balance and make it well. As a result, while the first one has a blind faith in Western methods of economic and social planning, while the second refused absolutely and stick to the principles of Islam.

With the failure of the capitalist system, and deemed necessary breakthrough and alternative, namely by applying Islamic bank that knows no interest but based sharing system. Islamic Banking is expected to function as an agency administrator (intermediary) between the owners of money to people in need of funds for the capital, through the principle of sharing and mutual insurance. In addition, the Islamic financial institutions is also expected to be responsible running supervision (auditing, account creation), entrusted the mandate (public funds). Of course, also maintain accountability of that entrusted. Nevertheless, the financial system that has grown Islamic need to get priority and socialization, as any other economic system has been rooted in society

Evolving and has been the division of the current economic system into two camps system of "liberal capitalism" and "socialism-marxism" that both can not be removed root and epistemic metaphysical outlook is relatively the same. However, in the economic sector is not an area that is "value-free". Practical activities (behavioral economics) has a horizon of meaning in terms of interest and ethics in accordance with the foundation of the metaphysical, epistemic, and views on property rights as well as the nature of social life. Both ideologies differ in the understanding of the philosophy of property rights and social life, so that justice can not be measured by the dimension of "numbers", but also must be measured also by the dimension of "taste" and "human wholeness".

Understanding the philosophy of property rights and social life as taught by the above two objectives, one individual and one collective. Nevertheless the two met on the same assumption that the property does not have a transcendental dimension (Belief) but merely immanent (worldly). In social life, giving to the neighbor comes from the attitude of compassion alone, not because of divine obligation, and even granting (assistance) is 
increasingly losing significance knowledge on humanity except for political purposes.8 For that "Islamic Economic System" to provide solutions and alternatives to the disadvantage of both the capitalist system and the socialist system.

\section{Islamic Principles Financial Institutions and Business Law \\ a. Principles of Business Law}

Economic legal studies (business) is a relatively new legal study. The study of economic law based on the further growth of thought and consciousness to create a legal system as an agent of development (the law as a means of development), the agent of modernization (the law as a means modernzation), and the law as a tool of social engineering (the law as a means of social engineering), Various opinions expressed about the need to study the laws of economics and what the background of the birth of the economic law. Rachmad Sumitro ${ }^{9}$ argues that the growing economic law for the interference of the government in the matter of self-interest, thus the rights and interests of individuals are restricted in the public interest. Therefore, the government set up in the civil law with consideration for increase welfare of the people in general.

Another understanding of the

8 Priyono $A E$, et al., 1985, Islamisasi Ekonomi: Suatu Sketsa Evaluasi dan Prospek Gerakan Perekonomian Islam, PLP2M, Yogyakarta, p.2.

9 Rochmad Sumitro, Hukum Ekonomi (Ekonomic Law), working at a symposium Kestas National Legal Development, BPHN 1978, cited by Neni Sri Imaniyati, 2002, the Law and Islamic economics development, Mandar Maju, Bandung, p. 70. legal study economics (business) as stated by Sri Redjeki Hartono ${ }^{10}$ is very broad because it covers two scopes, namely: First, the setting of economic development efforts in terms of improvement of national macroeconomic life. Second, efforts to sharing economic development evenly. So that economic law is a legal device that regulates the economic activities carried out by economic actors, both nationally and internationally.

From the above, it appears that the laws of economics lies in the field of civil law and public law field, the balance of interests of individuals and the public interest is maintained to achieve common prosperity. Therefore the economic law built by the principles of law derived from public law and legal principles derived from private law. Economic legal principles derived from the principles of public law, and the principle of state intervention in the economic activity. While the legal principle derived from civil law or commercial law basically only contains one side only, which is specifically about the legal relationship of the parties in a particular activity.

Law, man and society is a set of terms that can not be separated in the economy or business context. Law as rules of behavior that can be treated to regulate relationships among people and between people and their communities. The rapid economic growth and the complex spawned various forms of business cooperation.

Traffic is a complex business needs to set the values of ethics in running the business, so that ethics can

10 Sri Redjeki Hartono, op.cit, p.39. 
be used as guidelines, standart, measure to assess human behavior is good and bad in business. Business ethics involves the application of the principles of ethics in the business world that "justice and Ihsan". Islam teaches that in public life has always upheld the values of justice and Ihsan (QS. 16:90). Values of justice require among other things that people give to others something which they are entitled. While charity is that people do act goodness beyond the obligations that have been set. ${ }^{11}$

Concern for business ethics has been there for the rest of the business itself. There are some reasons to run a business is required ethics ${ }^{12}$, namely: First, the business is not only aiming for profit alone, but need to consider human values, if you do not want to sacrifice the lives of many people, so the people concerned that business conducted ethically.

Second, Business conducted among one with another human being, thus requiring ethics as guidelines and orientation for the decision, activity and human behavior in dealings (business) each other.

Third, A business with a very tight competition, so if in doing business due regard to ethical norms in an increasingly professional business climate it will win.

Fourth, Legality and morality related to, but different from one another, as a business activity that is acceptable, not necessarily ethically acceptable.

11 Azhar Ahmad Bashir, 1993, Reflesi atas Persoalan Ke-Islaman, Mizan, Bandung, p.177.

12 Sondra P. Siagian, 1996, Etika Bisnis, Pustaka Binaman Pressindo, Jakarta, p., 18-19.

\section{b. Islamic Financial Institutions}

As a religion revealed by God through the Prophet Muhammad. Islam was perfect and complete to organize man and his life in this world. Islam provides guidance in all aspects of life. Economic field is also not escaped the attention of Islam, even Islam only give broad outline only in regulating the economic problems this provides opportunities to developt and community dynamics that are always evolving. The existence Islamic economics also gives to man to be able to develop an economic system which conform to human nature as a vicegerent on earth.

Islamic economics, but have the basics own, also less influenced by the behavior of Moslems, namely ethics, values, norms and ideology. Islamic economics as the study of science can not be separated from the three framework underlying philosophical foundation of building the system, namely the ontological (about the study object or nature of knowledge is concerned), epistemology (how to obtain it or to question its methodology), and axiology (discussing the usefulness of the knowledge in question)

In economic terms the same language with the word al-'iqtisad, which literally means: simplicity, and cost-effective. Islamic economic sense by Umer Chapra ${ }^{13}$, Is the branch of science that help to realize human welfare through relocation and

13 M.Umer Chapra, New Landscape for Economic Future, Interpreting Amdiar Amin, et al., 2000, from the book, The Future of Economic: An Islamic Perspective, SEBI, Jakarta, p.131. 
distribution of resources in accordance with the number of al-'iqtisad al-Islam or the purpose of the enactment of Islamic, without restraining the freedom of the individual in excess, causing macroeconomic imbalances and ecology, or undermine family and social solidarity and moral guarantee of society. Umer Chapra economic outlook should link the economic issues with the social problems of humanity which is the goal of Islamic. So do not merely meet the needs of material as developed capitalist economists.

Islamic economic system aimed at creating long-term economic growth and maximize human welfare (Falah). Falah means fulfilled the individual needs of the community by not ignoring the macro-economic balance (social interest), the ecological balance and due regard the family values and social norms. So too the Islamic financial system that is free of interest principle is expected to be the best alternative in achieving the welfare of the people.

Basically that the principles Islamic economics is as follows.

1) The principle of Tawhid. This principle Islamic economics is essential because it teaches man the principle that in a relationship of humanity (horizontal relationships), as important relationship with God (vertical relationship). In a sense, man in pull through its economic activity is based on social justice rooted in the Qur'an. Thus the absolute ownership only possessed by Allah SWT., While the man ownership is relative.

2) The balance principle. Economic resources should be directed to achieve world prosperity and welfare of the hereafter as well. Islam emphasizes the harmony between inner and outer, between the individual and society, the balance needs of individuals and the needs of the community (general).

3) The principle of the Caliphate. In this principle of human Caliphate (representative) of God on earth who should run the rules and laws that have been established giver "mandate" Caliphate, ie Allah. To support the work of the Caliphate, humans equipped with a variety of abilities and spiritual potention, in addition supplied the source material that allows the execution of the mission can walk or be achieved effectively.

4) Principle of Justice. This principle is an important principle in Islamic economy mechanism. To be fair in the only major economic and based on especially the Qur'an and Sunnah, but besides that, based on the law of nature (sunnatullah) in which the world was created based on the principles and justice. Fair in the economy can be applied in determining the price, the quality of production, treatment of workers, and the effects of economic policy is issued.

\section{Financial Institutions in Islamic Banking Policies in Indonesia}

Financial and banking policies in order to boost economic growth in the sector both macro and micro. Deregulation of the national banking system was started in 1983 and a peak issuance of Act No. 10 
Of 1998 on changes to Act No. 7 of 1992 there is a change substantially. The principal changes include the following assertion of the independence of Bank Indonesia in coaching and banking supervision by transferring the entire licensing authority in the banking sector which was originally located on the finance minister to the head of Bank Indonesia.

The more important changes in the law is the ease of implementation of the "principles of Islam" in the bank's business activities, with the possibility of Banks for their business activities as well as running a conventional and financing patterns and other activities based on the "principles of Islam".

The enactment of the banking legislation raises great expectations for growth and development Islamic Banking and other financial institution that uses the principles of Islam in Indonesia. The government's commitment provides ease of implementation Islam principles in the banking business is one manifestation of the demands of the global market, especially in a range of diversity of products offered, as well as the system used.

Birth of Islamic banking motivated by the needs of the community (Moslems in Indonesia) to the bank without interest, which impacts significantly change the banking system in Indonesia. Islamic bank is one form Islam economic institutions. Islam as a comprehensive and universal teachings, set (mu'amalah) which can be applied in every time and place. In mu'amalah field, especially in the economic field Islamic provides principles and ethics that can be the guiding framework Islam economics.
Islamic economic principles ${ }^{14}$ among others:

a. Man is a creature of the mandate of Allah. for the prosperity of life on earth and given the position as caliph (His representative) who shall carry out his instructions.

b. Earth, sky, and everything in it was created to serve the interests of human life, and required him to meet to meet the trust of Allah SWT. and Allah. also the owner absolute control over all creation.

c. A person must work to make ends meet.

d. Real work is to produce (productive).

e. Rights belong to man burdened with obligations intended for the benefit of society and the social function of property rights.

f. State intervention is justified in order to control the economic activities towards the achievement of the objectives and the realization of social justice.

Departing from the principles Islam economics, Islamic Bank offers banking services with a variety of advantages. Analysts banks recognize the benefits of the services offered by the Islamic bank as a financial transaction concept is very modern and advanced ${ }^{15}$ it is in respect of services provided by the Islamic banking is not merely a service offered by conventional banks (commercial banks), but also the services usually provided by a modern conventional finance institutions

14 Azhar Ahmad Bashir, 1999, Berbagai Aspek Ekonomi Islam, P3EI-FE, UII, in cooperation with Publisher Tiara Wacana, Yogyakarta, p.13-14.

15 Sutan Remy Syahdaeni, 1999, Perbankan Islam Dan Kedudukannya Dalam Tata Hokum Perbankan Indonesia, Grafiti Cooperation with Adikarya Foundation, IKAPI, Jakarta, p. 2. 
(multi-finance company).

Another advantage is that there is a balance between protection of sharia bank as a service provider and the customer to the interests of both sides. In addition, in Islamic banks helping their function (ta'awun) unlike in conventional banking and sharia bank provides financing facility called al-qardhul hasan, which is an embodiment of an Islamic economic system in view of property or ownership treasures are the rights of Allah. Which must be removed to be given to those who qualify, like charity, donation, sadaqah, so the system hasan al-qardhul called the cost virtues that are non-profit and social nature.

\section{Islamic Economic Dispute Resolution \\ Islamic Economy (economics associated with Islamic values) can be seen from the two approaches, namely:} (1) from the point of economic law disciplines, and (2) from the perspective of economic law science. Economic legal studies, a lot of attention jurists' from the beginning until now. Halal-haram issue is concerning the study of law and in this case can not be separated from al-Ahkam al-Khamsah (the rules of law). Every attitude or actions of individuals, must be linked to one rule, namely haram (forbidden altogether), mandatory (to be done), makruh (preferably left), Nadab, or sunnah (should be done), or permissible (basically permissible), Study Science wider economic law than (just) the study of law and economics. The initial assessment.

The laws of economics or financial institution Islam in Indonesia seemed to get in touch with fiqh jurists'. In the field "Islamic Banking", for example, is mentioned in several of Article Act As Act No. 7 of 1992 on Banking as amended by Act No. 10 of 1998 and Act No. 23 of 1999 concerning Bank Indonesia as amended by Act. 3 of 2004.

Nevertheless, until the enactment of Act No. 21 of 2008 concerning Islamic Banking, there is no special Law governing Islamic Bank in general. The setting is only just through Bank Indonesia Regulation (PBI) and Bank Indonesia Circular Letter (SEBI), for example is Bank Indonesia Regulation No. 6/24 / PBI / 2004 Concerning Commercial Banks Conducting Business Based on the Islamic principle, Bank Indonesia Regulation No. 6/9 / PBI / 2004 regarding the DPM Allowance for Productive Activities for the Rural Islamic banking . Bank Indonesia Regulation No. 3/9 / PBI / 2003 on Activity Earning Allowance for Islamic bank and Bank Indonesia Circular Letter No. 6/9 / DPM Of 2004 on Procedures for Granting ShortTerm Financing Facility for Islamic banking 16

Islamic economics is different from conventional economics developed in the world today. The first is tied to the values of Islam and the second breakaway of the faith from western countries adhering to secularism and secularization of political run. Yet, there is no separate economic value or human behavior, but in conventional economics, the value used is the values of worldly (profane). Study Economics in general is actually about human behavior attitude towards the problem of production, distribution,

16 Rifyal Kaaba, Penyelesaian Sengketa Ekonomi Syariah Sebagai Sebuah Kewenangan Baru Peradilan Agama, Introduction Lecturing XVII Forces 2005/2006, Master Program (S-2) Law Faculty in Indonesian Islamic University (UII) in Yogyakarta on May 6, 2006, p. 2-3. 
consumption of commodities and services. Study of Islamic economics is no different in terms of the economy secular, but in another way it is tied to the values of Islam. ${ }^{17}$

Islamic law as a law of life in Indonesia is experiencing significant growth in the period of independence. These developments are, among others, can be seen from the authority possessed by the Religious Courts (PA) as the Islamic Courts in Indonesia. Formerly, the Religious Court decision purely based on jurisprudence jurists', the execution must be confirmed by the General Court, the judges only traditional Islamic educated and uneducated public, the organization does not culminate to the Supreme Court, and others. Now the situation has changed. One fundamental change lately is: Addition authority in a religious court Justice Law a new religion (Act No. 3 of 2006), among others, the economic field sharia. ${ }^{18}$

Article 49 letter (i) of the Act No. 3 of 2006 on the Religious Courts Religious Courts stated that the duty and authority to examine, decide and resolve cases within the economic field of Islamic. Explanation letter (i) of this article states that the "Islamic Economics" is the act or the business activities carried out according to the principles of Islam, among others, include:
a. Islamic Bank;
b. Macro Financial Institutions Islamic;
c. Islamic Insurance;
d. Islamic Reinsurance;
e. Islamic mutual funds;
f. Islamic Bonds and Islamic Medium Term Securities;

g. Islamic Securities;

h. Islamic financing;

i. Islamic pawnshops;

j. Islamic Financial Institutions Pension Fund;

k. Islamic Business.

Experience National Islamic Arbitration Board (BASYARNAS) in resolving the dispute between the bank and its customers Islamic can be a lesson for the Religious Court in resolving the "economy of Islam" in the future. Actually BASYARNAS can develop "Tahkim Institutions" that already exist in the repertoire Islam law, but this was not done because of various obstacles. The same experience might be repeated in the practice of Religious Courts in the future, when the Islamic economic disputes are not handled carefully and not pure resolved in accordance with Islamic principles. ${ }^{19}$

\section{CONCLUSION}

From the above description can be concluded as follows, that the existence of a financial institution Islam in the legal system of banking and legal dispute settlement authority, Economics with the breath Islam values, so-called "Islamic economics" or in other words "economy of Islam" is a reflection of" faith "and" Islamic "in Islamic doctrine, ideas for developing an economic system based on the teachings of Islam, Islamic economics or economic form Islam is a necessity in the service economy of Moslems who are inseparable from the values of faith who believed; Economic law, originally a private law deemed personal problems, in the perspective of the
17 Ibid., p. 1-2.

18 Ibid., p. 1.
19 Ibid., p. 8-9. 
future for the public good needs to be raised partly into public law, the government needs to intervene for the sake of the common good; As an economic system, Islamic financial institutions needed in order to finance the system settings and service of people, taking into account economic functionalization Islamic law, both concerning the stages of formulation, application and execution, all of which can not be released principle of law, namely: "Fair and Ihsan"; Financial institutions in Islamic economic system of banking law in Indonesia, protection and legality, namely: contained in Article of Act No. 7 of 1992 concerning Banking, like as amended by Act No. 10 of 1998 and Act No. 231999 About Bank Indonesia, which was amended by Act No. 3 Of 2004.dan; Islamic economic dispute settlement concerning: (a) Islamic banking , (b) Islamic Macro Financial Institutions, (c) Islamic Insurance, (d) Islamic Reinsurance, (F) Islamic Bonds and Medium Term Securities, (g) Islamic Securities, (h) Islamic Financing, (i) Islamic Bonds, (j) Islamic Pension Fund, (k) Islamic Business under Article 49 letter (i) of the Act N0. 3 of 2006 on the Religious Courts Religious Courts stated that the duty and authority to examine, decide and resolve cases within the economic field of Islamic.

\section{BIBLIOGRAPHY}

Azhar Ahmad Bashir, 1993, Reflesi atas Persoalan Ke-Islaman, Mizan, Bandung.

Azhar Ahmad Bashir, 1999, Berbagai Aspek Ekonomi Islam, P3EI-FE, UII, in cooperation with Publisher Tiara Wacana, Yogyakarta.

Bambang Suprabowo, Anis Mashdurohatun and Eman Suparman, The Inhibiting Factors On Legal Protection For Recipients Of Fidusiary Warranties With Guaranted Inventory Objects, South East Asian Journal of Contemporary Business, Economics and Law, Vol. 13, Issue 4 (Augustl), 2017.

Dawam Rahardjo, 1999, Islam dan Transformasi Sosial-Ekonomi, LSAF, Jakarta.

Ismail Saleh, 1990, Hukum dan Ekonomi, PT. Gramedia Pustaka Utama, Jakarta.

M.Umer Chapra, New Landscape for Economic Future, Interpreting Amdiar Amin, et al., 2000, from the book, The Future of Economic: An Islamic Perspective, SEBI, Jakarta.

Priyono $A E$, et al., 1985, Islamisasi Ekonomi: Suatu Sketsa Evaluasi dan Prospek Gerakan Perekonomian Islam, PLP2M, Yogyakarta.

Rifyal Kaaba, Penyelesaian Sengketa Ekonomi Syariah Sebagai Sebuah Kewenangan Baru Peradilan Agama, Introduction Lecturing XVII Forces 2005/2006, Master Program (S-2) Law Faculty in Indonesian Islamic University (UII) in Yogyakarta on May 6, 2006. 
Rochmad Sumitro, Hukum Ekonomi (Ekonomic Law), working at a symposium Kestas National Legal Development, BPHN 1978, cited by Neni Sri Imaniyati, 2002, the Law and Islamic economics development, Mandar Maju, Bandung.

Sondra P. Siagian, 1996, Etika Bisnis, Pustaka Binaman Pressindo, Jakarta.

Sri Redjeki Hartono, 2000, Kapita Selekta Hukum Ekonomi, Editor, Husni Syawali and Neni Sri Imaniyati, Masdar Maju, Bandung.

Sunarjati Hartono, 1982, Hukum Ekonomi Pembangunan Indonesia, Bina Cipta, Bandung.

Sutan Remy Syahdaeni, 1999, Perbankan Islam Dan Kedudukannya Dalam Tata Hokum Perbankan Indonesia, Grafiti Cooperation with Adikarya Foundation, IKAPI, Jakarta.

Syed Nawab Haider Nagvi 1981, Ethies and Economics: An Islamic Synthesis, The Islamic Foundation, Leicester.

General Explanation of Law No. 7 of 1992 on Banking, and the Act was amended by Act No. 10 of 1998 on the Amendment to Act No. 7 of 1992 on Banking. 